\title{
UNIVERSITYOF
}

FORWARD

THINKING

WESTMINSTER用

WestminsterResearch

http://www.westminster.ac.uk/westminsterresearch

The New Phantasmagoria: Transcoding the Violence of Financial Capitalism

Spencer, D.

This is an Accepted Manuscript of a book chapter published by Bloomsbury Academic in Lahiji, N. (ed.) The Missed Encounter of Radical Philosophy with Architecture London, New Dehli, New York, Sydney, Bloomsbury, pp. 79-94 on 10h April 2014, available online:

http://www.bloomsbury.com/uk/the-missed-encounter-of-radical-philoso...

The WestminsterResearch online digital archive at the University of Westminster aims to make the research output of the University available to a wider audience. Copyright and Moral Rights remain with the authors and/or copyright owners.

Whilst further distribution of specific materials from within this archive is forbidden, you may freely distribute the URL of WestminsterResearch: ((http://westminsterresearch.wmin.ac.uk/).

In case of abuse or copyright appearing without permission e-mail repository@westminster.ac.uk 


\section{The New Phantasmagoria: Transcoding the Violence of Financial Capitalism}

Radical philosophy may thus far have missed a critical encounter with contemporary architecture, but architecture has, for some time, encountered theory as the instrument of its own disciplinary reinventions. Since the late $60 \mathrm{~s}$, architecture has imported from theory, especially in its 'continental' variants, a range of concepts with which to freight its own discourse as radical, or as at least 'progressive'.

From the Situationist International and the événements of Paris May 68 Bernard Tschumi, at the Architectural Association in London in the early 70s, derived his architecture of 'events', while Nigel Coates (also at the AA) borrowed from their 'psychogeography' to fabricate a narrative approach to architecture and urbanism. In the 80s Tschumi, alongside others, most notably Peter Eisenman, then took the philosophy of deconstruction as the inspiration for the invention of a 'deconstructivist' architecture (Eisenman even working with Derrida on a design proposal for the Parc de la Villette in Paris). ${ }^{1}$ By the early 90s, following the movement of a broader Deleuzian turn in theory itself, it was to the thought of Gilles Deleuze and his writings with Félix Guattari that certain architects and architectural theorists began to express their allegiances.

This architectural 'Deleuzism'² initially centred on Deleuze's The Fold: Leibniz and the Baroque, ${ }^{3}$ and the chapter '1440: The Smooth and the Striated', from A Thousand Plateaus: Capitalism and Schizophrenia. ${ }^{4}$ A special edition of Architectural Design, titled Folding in Architecture, was published in 1993 featuring essays and projects by Peter Eisenman, Greg Lynn and Jeffrey Kipnis, among others. ${ }^{5}$ Its contributors sought to correlate Deleuze's account of 'the fold' in the philosophy of Leibniz with the formal complexity of a 'new architecture' (as Kipnis had called it). ${ }^{6}$

Conceptually related to the fold, the schema of the smooth and the striated was originally elaborated in A Thousand Plateaus to articulate the relations between open and closed systems in technology, music, mathematics, geography, politics, art and physics. Smooth space was figured as topologically complex, in continuous variation and fluid. This was a space through which one drifted, nomadically. Striated space, by contrast, was defined by its rigid geometry, a territory carved into functional 
categories channeling the movements of its occupants along the pre-inscribed lines of a Cartesian grid. Striated space was standardized, disciplinary and imperial. Again, these concepts, particularly Deleuze and Guattari's implicit (though qualified) privileging of smooth space and continuous variation over static geometry, were found to resonate with architecture's engagement with complex topologies. ${ }^{7}$ At the same time, they were used to imbue architecture's move to formal experimentation with philosophically radical implications. The virtues of Deleuzian 'smoothing' and the pursuit of 'continuous variation' were affirmed in the architectural writings of Lynn, Reiser and Umemoto, Zaha Hadid, Patrick Schumacher and Alejandro ZaeraPolo, among others, so as to suggest the philosophical substance of the complex formal modulations characteristic of their work. ${ }^{8}$

The usefulness of Deleuze and Guattari's philosophy to architecture was not confined, however, to servicing it with the formal tropes of folding and smoothing.

Architecture's Deleuzian turn also offered the discipline an escape route from its prior entanglements in the linguistic and semiotic paradigms of postmodernism and deconstruction. The new Deleuzian orientation, wrote Kipnis, marked a turn from 'post-structural semiotics to a consideration of recent developments in geometry, science and the transformation of political space, a shift that is often marked as a move from a Derridean to a Deleuzean discourse'.

What was decisive in this new theoretical orientation, however, was not just its switching from linguistically based paradigms to more 'properly' architectural concerns with space, form and geometry. The Deleuzian turn in architecture also marked the initial stages of its still ongoing mission to disengage itself entirely from the perceived dead end of theory's critical negations, and to forge a new alliance with the corporate and managerial agendas of neoliberalism.

\section{Trouble in theory}

The trouble with theory, especially of the type once so eagerly embraced by architecture, had been that the perspectives it opened up tended to be deeply destabilizing and unsettling, particularly for any host discipline aiming to selectively harness these to its own agenda. As François Cusset has observed, 'Sometime in the third quarter of the twentieth century, in France but not only there, theory joyfully 
stopped making sense, and began cracking all existing frames...theory used to be reasonable, more than strictly rational, and for some reason which remains to be fully explained theory turned crazy ${ }^{, 10}$ Unleashed from the lieu propre of Hegelian dialectics and freed from the confines of its disciplinary demarcations - by figures such as Althusser, Foucault and Derrida - theory began to produce 'a transdisciplinary open field, loose yet closely related to literature, politics and psychoanalysis'. ${ }^{11}$ Theory turned 'crazy', Cusset suggests, because its critical labour was endlessly multiplied and turned against itself with every encounter it staged between once discrete fields of knowledge. It lost its identity in the multiple displacements, doubts and suspicions arising from these encounters. Troubled and troubling, theory became a 'demon' that 'began to possess the Western intellectual body'. 12

Something of theory's demonic quality is also apparent in the description of its encounter with architecture given by K. Michael Hays in the introduction to his Architecture Theory since 1968:

From Marxism and semiotics to psychoanalysis and rhizomatics, architecture theory has freely and contentiously set about opening up architecture to what is thinkable and sayable in other codes, and, in turn, rewriting systems of thought assumed to be properly extrinsic or irrelevant into architecture's own idiolect. ${ }^{13}$

Throughout the period from 1968 to 1993 with which Hays's anthology is concerned, theory may be conceived as a demonic, troubling presence within architecture - at the same time as an exhilarating one - since it forges all manner of unforeseen connections between architecture and language, the unconscious, capital, class and gender, and, locating these in the forms, practices and structures of architecture, shows them residing in the very places where the discipline might have thought itself able to locate its autonomy. Rather than finding itself straightforwardly enriched by such encounters, architecture, like theory itself, in its relentless work of translation, correlation and displacement, found its foundations unsettled and, according to some, its mission compromised. Michael Speaks, for example, writes that theory 'attached' itself to architecture and then drove it towards a 'resolutely negative' condition. ${ }^{14}$ 
The Deleuzian turn was also related, in significant ways, to the subsequent emergence of a 'post-critical' architectural discourse. Marked by the publication of Robert Somol and Sarah Whiting's 'Notes Around the Doppler Effect and Other Moods of Modernism' in the journal Perspecta in 2002, the post-critical position argued that critique was extrinsic to the 'proper' concerns of architecture and served the discipline only as a counterproductive form of 'negativity'. ${ }^{15}$ Alejandro Zaera-Polo (principal, with Farshid Moussavi, of the now defunct Foreign Office Architects), for instance, described the critical, in its negativity, as inadequate to deal with contemporary levels of social complexity. Deleuze, in contrast, offered insight into this condition and affirmed its productivity:

[The] paradigm of the 'critical' is in my opinion part of the intellectual models that became operative in the early 20 th century and presumed that in order to succeed we should take a kind of 'negative' view towards reality ... today the critical individual practice that has characterized intellectual correctness for most of the 20th Century is no longer particularly adequate to deal with a culture determined by processes of transformation on a scale and complexity difficult to understand ... you have to be fundamentally engaged in the processes and learn to manipulate them from the inside. You never get that far into the process as a critical individual. If we talk in terms of the construction of subjectivity, the critical belongs to Freud a Lacan [sic], what I called 'productive', to Deleuze. ${ }^{16}$

More bluntly, Kipnis described criticality as a 'disease' that he wanted to 'kill', 'once and for all'. ${ }^{17}$ Today, the post-critical has become a new orthodoxy within certain tendencies in architecture, and its attacks on criticality are no less strident or (paradoxically) negative than those of Zaera-Polo or Kipnis. In his The Sympathy of Things (2011), Lars Spuybroek describes the twentieth century as 'our true Dark Ages' ${ }^{18}$ Among the horrors that define it as such for Spuybroek, including those of Auschwitz and nuclear weapons, he reserves special mention for the objects of postcriticality's censure: 'we even survived semiotics and deconstruction. And criticality too., 19

The castigation of critical 'negativity' has been extended further (and from the same quarters), into arguments against thought, cognition, and intellectual reflection as 
conditions of architectural and spatial experience. In their place affect, complexity, networked relations, new materialisms and new vitalisms are now privileged. Kipnis, for instance, has stated that now is the 'time of matter', not ideas. This principle, he argues, derives from the origins of the universe: 'There were no signs, no ideas, no concepts, no meanings, no disembodied spirits, no dematerialized abstractions whatsoever around during the first couple of seconds after the Big Bang, nor during the first million or billion years, or, for that matter, even these days. ${ }^{20}$

For Spuybroek, 'meaning' is a 'horrible word that lets us believe that the mind can trade aesthetics for textual interpretation'. ${ }^{21}$ Ideas and intelligence are properties of the relations between life, matter and technique, rather than products of the mind. 'Matter' he writes, 'can think perfectly well for itself'. Humans have no special place or distinctive capacity within Spuybroek's world of 'things'; a world in which all relations are ones of 'sympathy', understood as 'the power of things at work, working between all things, and between us as things'. 'Humans', he says, 'are nothing but things among other things'. ${ }^{22}$ Reified in this fashion, human subjectivity is relieved of its interpretive, reflective and critical capacities and required, instead, only to give itself over to the immediacy of purely affective relations passing between things.

Alejandro Zaera-Polo, likewise affirming the primacy of affect over intellect and matter over meaning, has outlined the implications of this position for architecture. 'The primary depository of contemporary architectural expression' he writes, in his essay 'The Politics of the Envelope', 'is now invested in the production of affects, an uncoded, pre-linguistic form of identity that transcends the propositional logic of political rhetorics. ${ }^{23}$ Pursuing a similar line of argumentation, Sylvia Lavin, in her Kissing Architecture, has proposed a 'kissing [intimately relational] architectural surface', which is not 'legible and demanding of focused attention', but that is 'affective and eidetic because it shapes experience through force rather than representation. ${ }^{24}$

From this position contemporary architecture is able to release itself from any obligation to articulate an intelligible relationship to the social. In place of this it proposes to produce a purely sensible and immediately experiential condition through the fabrication of 'atmospheres' and 'environments' through which subjects may be 
steered. In the second volume of Patrik Schumacher's The Autopoesis of Architecture, for example, he tasks contemporary architecture with 'channeling bodies' and 'guiding subjects' through the design of such environments. ${ }^{25}$ Questions and representations of the political, the social, and the economic are to be excluded from consideration in the design of these environments, on the basis that we now inhabit some form of pre-linguistic or post-representational world, or that these concerns should be placed, as Schumacher has argued, beyond the purview of architecture, ${ }^{26}$ or, according to Zaera-Polo (following Manuel De Landa in this), because it is probably best not to speak any longer of larger totalities such as capitalism or society. ${ }^{27}$ Rather than to a capitalist axiomatic of growth and accumulation, it is to matter, now construed as productively complex, self-organizing, networked and creative, that power is ascribed. Architecture should, it follows, understand its practice as operating in accordance with this understanding. Its selfassigned task is to organize the relations between a reified subjectivity and a vitalized matter.

From its initial turn to Deleuze and Guattari, then, this architectural current has arrived at an argument accounting for architectural design and spatial experience as practices of pure immediacy. The question of mediation — of the relation of this architecture to the operation of power (other than as an immanently materialist one), on the one hand, or to the social subjects of its operation, on the other-has, it is supposed, been entirely superseded. Furthermore, architecture has extricated itself from the troubling nature of radical thought, either through ditching theory altogether, or through aligning itself with theorists who share its hatred of criticality, such as Bruno Latour, ${ }^{28}$ or with figures such as Manuel De Landa, who have served them with a version of Deleuze and Guattari from which any Marxian residue has been wiped clean. ${ }^{29}$ It is precisely at this juncture, and on these terms, however, that the prospect of a critical re-encounter between radical philosophy and the type of architecture discusssed here emerges. The first task of this re-encounter would be to address the relations between architecture and the larger totalities that its discourse has suggested lie beyond its proper concerns, or refused even to countenance the existence of.

\section{Becoming Progressive}


Architecture has not been alone in undertaking to refashion its identity and purpose according to vitalist and new materialist paradigms. The creative productivity imputed to networks, complexity, emergence and self-organisation has, in fact, been embraced across a wide range of social, economic, political, institutional and commercial fields. Advocate of the 'digital economy', Don Tapscott, for instance, writes that 'The industrial hierarchy and economy are giving way to molecular organizations and economic structures. ${ }^{30}$ In their book It's Alive: The Coming Convergence of Information, Biology, and Business, Christopher Meyer and Stan Davis observe:

we will again have scientific management—-but this time the underlying science will be 'general evolution'. The theories that drive biology will be adopted in the way we use information, and the way we manage our enterprises. Biology, information, and business will converge on general evolution. ${ }^{31}$

Such developments in business management have been acknowledged by figures such as Schumacher and Zaera-Polo as significant for architecture's future orientation. Schumacher has argued that architecture should translate the 'new social tropes' of contemporary organizational models into new 'spatial tropes'. ${ }^{32}$ Architecture, he suggests, not only becomes more relevant in servicing these organizational models, it also joins them in affirming what is described as an 'emancipatory' project of producing de-hierarchized, flexible and informal networks. There is, Schumacher writes, 'no better site for a progressive and forward-looking project than the most competitive contemporary business domains'. ${ }^{33}$

Zaera-Polo has similarly argued for the progressive and productive qualities inherent to de-hierarchized and complex 'material organizations', understood as now encompassing economics, politics, infrastructures, education and cultural production. Claiming that "contemporary power structures operate as physical aggregates where behavior is created through the localized complex association of molecular components, ${ }^{34}$ he suggests that architecture will become progressive through aligning itself with such 'emerging complex orders'. 35

\section{Raw material}


Architects have thus acknowledged the widespread turn to the organizational models referred to here, and the contribution of their own practice to these, but have mystified the historical conditions of their appearance. To the extent that the origins of these models are addressed at all, they are typically held to have themselves 'emerged', zeitgeist-like, in the natural - and 'progressive' — course of things. In the latter thought of Deleuze (largely, and for obvious reasons, ignored within architectural writing), however, a succinct account is offered of how the appearance of complex, laterally organized and 'open' organisational models, across a broad spectrum of fields and practices, were coming to constitute a new and ever more totalizing form of power operating through what he termed 'societies of control' ${ }^{36}$ In perhaps one of the philosopher's most infamous statements on power, he warns: 'Compared with the approaching forms of ceaseless control in open sites we may come to see the harshest confinement as part of a wonderful happy past'. ${ }^{37}$

Deleuze's conception of a 'society of control' was, in part, developed from certain perspectives opened up in the earlier work of Foucault, whose Discipline and Punish first addresses the appearance a post-disciplinary society of 'lateral controls' in which 'the massive, compact disciplines are broken down into flexible methods of control, which may be transferred and adapted' ${ }^{38}$ In his subsequent analysis of neoliberalism, as a historically specific mode of governmentality, he described it operating as 'an environmental type of intervention instead of the internal subjugation of individuals' 39

Luc Boltanski and Eve Chiapello, in their The New Spirit of Capitalism, ${ }^{40}$ have produced a critique of contemporary networked, self-organizing and anti-bureaucratic models of workplace management attending, in depth, to their historical conditions of emergence. Worker's demands for 'autonomy' and 'self-management', articulated in the wake of May 68, they argue, were strategically subverted by employers' subsequent demands that workers should indeed manage themselves, though not in the cause of liberation, but of increased productivity and efficiency. Self-motivation, flexibility, and interpersonal skills, they argue, became the requisite attributes of a new organisational paradigm in which control was to be effectively internalized by the worker: 
'Controlling the uncontrollable' is not something with an infinite number of solutions: in fact, the only solution is for people to control themselves, which involves transferring constraints from external organizational mechanisms to people's internal dispositions, and for the powers of control they exercise to be consistent with the firm's general project. $^{41}$

Such analyses of the historical conditions under which the new organizational models developed, and of how they have been instrumental to new modes of power, all centre to some extent upon questions of subjection. Theorists of Italian post-operaismoPaolo Virno, Maurizio Lazzarato, Christian Marazzi, Antonio Negri ${ }^{42}$-have, in their accounts of 'general intellect' and 'immaterial labour', been especially concerned with the ways in which contemporary techniques in management and organization are now invested in the production of subjectivity, rather than, or at least alongside, those of commodity production. These organizational techniques are, they have argued, addressed to the subject's communicative, creative and affective potentials, and to the mobilization of these in the production of value. 'If production today is directly the production of a social relation', writes Maurizio Lazzarato, 'then the raw "material" of immaterial labor is subjectivity and the "ideological" environment in which this subjectivity lives and reproduces. ${ }^{43}$

While this current of radical thought has long been concerned with the ways in which, under post-Fordism and neoliberalism, subjectivity becomes the 'raw material' of valorization, it has also attended to the existential insecurities and 'precarities' that the subject is exposed to in the all-pervasive financialization of the economy. The 'violence of financial capitalism', as Marazzi has recently described it, stems precisely from the fact that financialization is not confined to a specific sector of the economy, or to a particular aspect of social practice, but is spread throughout its entirety. Furthermore, it is through networked and laterally connective conditions, ones that architects and the gurus of new managerial models alike have affirmed as progressive, that financialization, with its concomitant precarities and crisesespecially evident in the wake of the financial crisis of 2007/8 — seeps into all the spaces and times of everyday life. This all-pervasive condition of financialization may, then, be understood as operating through the same 'open' systems as those that characterize Deleuze's 'societies of control'. Continuous modulation and lateral 
connectivity constitute both an apparatus of control and a medium of financialization. In fact, these two functions combine to form a particular mode of governmentality.

As Lazzarato has argued, in his The Making of the Indebted Man, the social and existential conditions produced through financialization are not the result of some merely temporary glitch in the system - as the term 'crisis' problematically impliesbut serve as a technique for the production of a compliant subjectivity for that system. 'Governmentality', he writes, 'has produced a collective capitalist ... which is not concentrated in finance, but operates throughout business, administration, service industries, political parties, the media and the university. ${ }^{44}$ Jonathan Crary similarly observes in 24/7: Late Capitalism and the Ends of Sleep, that 'the elaboration, the modeling of one's personal and social identity, has been reorganized to conform to the uninterrupted operation of markets, information networks, and other systems. ${ }^{45}$ This relentless exposure of the subject to the logic of financial capital at all levels marks its violence; the violence of being compelled to be always at or available for work (paid or unpaid), to be always working upon oneself, in the acquisition of contacts, projects and connections, to produce in oneself the requisite mental dispositions and affective skills, and to make oneself mobile and flexible enough to survive the now normalized existential conditions of debt, precarity and crisis.

It is vital to the maintenance of this arrangement, of course, that these conditions are mediated, at the points where they are to work directly upon the production of subjectivity, in significantly more positive terms. Given the turn in architecture towards the accommodation of contemporary managerial paradigms, and its enthusiasms for the 'progressive' character of marketization, its contributions to this work of mediation ought to be addressed. Radical philosophy's re-encounter with architecture might concern itself, among other things, with how it is that an architecture identifying itself with a condition of uncoded and pure immediacy contributes, in fact, to the mediation, the affirmative 'transcoding', of financial capital. ${ }^{46}$ However seemingly anachronistic, it may be through the concept of the phantasmagoria, as employed first by Marx, and later by Walter Benjamin and Theodor Adorno, that some critical purchase on this concern may be gained.

\section{The matter of mediation}


Marx, in the first volume of Capital, invokes the concept of the phantasmagoria in his analysis of the fetishistic character of the commodity form:

The mysterious character of the commodity-form consists therefore simply in the fact that the commodity reflects the social characteristics of men's own labour as objective characteristics of the products of labour themselves, as the socio-natural properties of these things ... It is nothing but the definite social relation between men themselves which assumes here, for them, the fantastic ['phantasmagorisch' (phantasmagorical) in the original] form of a relation between things. ${ }^{47}$

Marx argues here that we do not, and in fact cannot, experience our social relations through face-to-face interaction, or directly through our labour, but only through the exchange of the things produced by our labour. The commodity-form of these things then takes on the fetishized quality through which our social relations are mediated: 'the labour of the private individual manifests itself as an element of the total labour of society only through the relations which the act of exchange establishes between the products, and through their mediation, between the producers. ${ }^{48}$ The phantasmagorical appearance of these relations - thing-like between people and social between things - conceals the actual conditions of labour in the fetish character of the commodity, but is not to be regarded simply as an optical illusion that might be removed by rational understanding. This phantasmagoria is, rather, the lived reality of the social relations Marx is describing, and through which these relations 'appear as what they are ${ }^{49}$, i.e., as necessarily mediated by things.

Without being entirely superseded, the conditions of labour, social relations and commodity production that Marx describes here have also been developed into the post-Fordist and neoliberal realms of immaterial labour with which the thought of Italian post-operaismo has been concerned. Now we also work upon ourselves, in and through the relational conditions that sustain the financialization of everyday life (and not simply, as before, so as to reproduce ourselves for work), so as to become, in effect, the exchangeable products of our own labour. It is our subjectivity that, through this productive labour, now itself becomes thing-like, a commodity defined by the exchange value of our knowledge, skills, and affective dispositions, of our adaptability, availability and flexibility. Marx's characterization of relations under 
industrial capitalism, as thing-like between people and social between things, might then be reformulated, for financial capitalism, as ones in which the social is a thinglike relation between people treated as things.

If these relations can be described as also appearing in phantasmagorical form, it is because the conditions of labour they necessitate are similarly concealed. Only now these are not, or not only, the working conditions of the factory, but the conditions of working upon oneself, of making oneself subject to the precarities, extended hours, and continuous training involved in fashioning the self for exchange, and of encountering others under conditions of what Virno has described as 'opportunism, cynicism and fear'. ${ }^{50}$ The discursive work of the new phantasmagoria consists of expressing these conditions in the affirmative terms of actor-networks, assemblages, self-organizing systems and new materialisms. When Spuybroek claims that humans 'are nothing but things among other things', for example, and that we are relieved of the burden of critical reflection through this knowledge, the supposed immediacy of his materialism actually operates as a form of mediation: the reification of subjectivity is presented as returning us to an ontological truth we should aspire to conform to, rather than one determined by the conditions of financial capitalism.

Marx used the figure of the phantasmagoria to analyze social relations in the general sense of their 'appearance'. In the phantasmagorical critique subsequently developed by Benjamin and Adorno, however, the term is deployed as means of analyzing specific forms of cultural and spatial production such as Wagnerian opera, Art Noveau, the Parisian arcade and World Fairs. It is from Adorno's account of the Wagnerian phantasmagoria in particular, though, that the following comments regarding contemporary architectural practice are derived.

In his In Search of Wagner, Adorno writes that the 'occultation of production by means of the outward appearance of the product' is the 'formal law governing the works of Richard Wagner.' ${ }^{51}$ The production referred to by Adorno here as 'occulted' concerns Wagner's compositional practice - 'the primacy of chromaticism and the leading note ${ }^{, 52}$ - but it also refers to the staging and performance of his operas. As Susan Buck-Morss has elaborated: 'At Bayreuth the orchestra-the means of production of the musical effects - is hidden from the public by constructing the pit 
below the audience's line of vision. ${ }^{53}$ Similarly the labour and techniques through which the Rhine Maidens appear to float above the stage, in Wagner's Der Ring des Nibelungen, are obscured from view. Hence Adorno considers the composer's work as essentially phantasmagorical according to the criteria already established by Marx: their conditions of labour are concealed, but the products of these appear in the commodified form of a fetishized object of consumption.

Today's architectural phantasmagoria are similarly invested in the 'occultation of production'. The actual working conditions of architectural production-short-term contracts, unpaid internships, long hours - rarely resemble, in practice, the type of dehierarchized and naturalized organizational models promoted within architectural discourse. These conditions, alongside the labour of the actual design processes and those of building construction, are rendered imperceptible in the smoothed forms and undulating surfaces that characterize the projects of practices such as Reiser + Umemoto, Spuybroek's NOX or Ali Rahim and Hina Jamelle's Contemporary Architecture Practice. Of course one would probably not want to dwell at length in any architecture premised, through a kind of Brechtian verfremdungseffekt, upon selfreflexively foregrounding its own means of construction and production. Nevertheless, contemporary architecture's fetishization of the continuous and biomorphic modelling of its surfaces and forms can be tellingly contrasted with other possibilities. In architectural Brutalism, for instance, labour and construction processes were revealed through the trace of the wooden shuttering indexed upon its concrete surfaces. Modernist architecture, more broadly, speaks of itself, in its shaping of form according to strict geometrical and/or functional principles, as at least implicitly resulting from the intellectual labour of a conscious design process. The contemporary architectural phantasmagoria, however, is made to appear as if it had produced itself, autogenetically emerging into the world independent of any practice of labour, design or construction.

Adorno identifies the purpose of this phantasmagoric mode of appearance in the work of Wagner. 'The product' he writes, 'presents itself as self-producing ... In the absence of any glimpse of the underlying forces or conditions of its production, this outer appearance can lay claim to the status of being. ${ }^{54}$ The architectural phantasmagoria may be said to operate in a similar fashion, but rather than to a 
transcendent conception of 'being', it lays claim to the immanence of a vitalised materialism and its immediate appearance as such. This immanence is expressed in a recurrent trope of contemporary architectural design where buildings, even entire urban systems and their infrastructural components, appear as having been collectively warped or deformed by an encounter with an abstract set of forces with which they are now aligned. Aedas/Aecom's West Kowloon Terminus, which is to connect Hong Kong to cities in the Chinese Mainland by rail, for example, appears to register, in its fluid, undulating morphologies, the passing of some great wave through the terrain from which it emerges. The design of the terminus also suggests, in its alternating bands of generic 'green space' and pedestrian pathways, the idea of an unconflicted and elegantly achieved convergence of infrastructure, nature and mobility. Conditions of friction, conflict and contestation - the processing of subjects through the protocols of immigration and customs, the environmental impact of largescale infrastructural projects - are mediated in the reassuringly naturalised and affirmative forms of an architectural phantasmagoria.

Work upon the acquisition of contacts, skills and information through continuous selfmobilization also constitute forms of labour 'occulted' by the architectural phantasmagoria. The compulsion to 'network', to move with the currents of a hegemonic connectivism, is facilitated by designs in which the ground is modelled as continuously ramped or wave-like. The ground planes of projects like Reiser + Umemoto's Foshan Sansui Urban Plan, or SANAA's Rolex Learning Center in Lausanne, remodel the relational imperatives of neoliberalism as artificial landscapes so as to imply an experience of freedom from the constraints of older, and more static spaces of containment. Likewise the trope of 'porosity' - exemplified in the openings that perforate the planes of both of these projects, or the envelope of ZaeraPolo/Foreign Office Architects' Ravensbourne College, punctuated with a network of circular fenestration and internally 'landscaped' circulation-mediates, as liberating, the conditions in which subjects must continuously expose themselves to opportunities for refashioning their subjectivity. In the case of Ravensbourne, these conditions of mobilization and exposure are derived from new models of educationthe 'learning landscape' for instance - through which students are to be 'released' from the traditional confinements of the 'ivory tower' and exposed to the entrepreneurial and business models through which their work will now be valorized. 
The Ravensbourne project, in common with the numerous 'hubs' and 'hives' with which older universities have now been retrofitted, is designed as the spatial complement to these models. ${ }^{55}$

Adorno, in In Search of Wagner, criticized, as 'totalising', the environments of the Wagnerian Gesamtkunstwerk in the following terms:

[T] he task of [Wagner's] music is to warm up the alienated and reified relations of men and make them sound as if they were still human. This technological hostility to consciousness is the very foundation of the music drama. It combines the arts in order to produce an intoxicating brew. ${ }^{56}$

Much contemporary architecture is also aimed at the production of an 'intoxicating brew', and for related ends. Through an appeal to the sensuous realm of pure affectivity, architecture, now conceived as the production of environments and atmospheres, affirmatively mediates financialization's existential conditions as ones of smooth transitions, liberating flexibility and vitalized mobility. It does so through the production of a totalizing aesthetic in which the subject is fully immersed. Designed to present an unbroken perceptual field of sensory experience, any inconsistencies or interruptions that might break its affective spell are to be eliminated. The ribboned undulations of a project such as Thomas Heatherwick's Pacific Hall mall in Hong Kong, for example, not only define the aesthetic character of its large scale elements, but are also to be found reproduced in the smallest of details, such as the elevator buttons, or the hinges of toilet doors specially designed so as to allow the designer to 'bend the wooden wall without any visible hinge or line'. 57 Likewise, in the architecture of Zaha Hadid detailing is used to produce what BuckMorss, in her account of the phantasmagoria, has termed a 'total environment' ${ }^{58}$ In projects such as the BMW Central Building in Leipzig or the MAXXI Museum in Rome, the circulational diagrams of the building, with their fluid trajectories and precisely calculated intersections, are rendered sensual through the detailing of walls and ceilings with the parallel linear elements that snake through their spaces. Here, the goal would seem to be to induce a synaesthesia between the internal sense of one's bodily movements - 'proprioception' - and the perception of ones external environment - ‘exteroception' — through which body and eye are seamlessly aligned 
with a movement sensualized as free-flowing and elegant.

The architecture of such environments offers its occupants no sensory relief from a totalizing aesthetic designed explicitly not to be read but to be felt, and affords no time or space, in its atmospheres, from which any distance from their affective work might be consciously reflected upon or interpreted. This is, therefore, an architecture that appears, or supposes itself, to have outmanoeuvred critique.

However, the ideas through which this supposition is maintained and affirmed - those of the post-critical and the post-linguistic, of the new materialisms and vitalisms where biology, society, and the market happily converge upon a benevolently dehierarchized model of organisation - should also be understood as a kind of phantasmagorical work. As a spurious form of historicism, through which contemporary conditions are affirmed as the herald of some fundamentally new paradigm that should now be adhered to, they conceal the longer historical continuities (even if ones of continuous change) within capitalism and power in which architecture, in this case, is, and has been for some time, implicated. As Crary has recenty written, in a similar context:

A logic of economic modernization in play today can be traced directly back to the mid ninetecnth century. Marx was one of the first to understand the intrinsic incompatibilily of capitalism with stable or durable social forms, and the history of the last 150 years is inseparable from the 'constant revolutionizing' of forms of production, circulation, communication, and image-making. ${ }^{59}$

Given that Crary also rightly identifies the most consitently used techniques over this period as those concerned with 'the management and control of human beings', we may say that the models through which these techniques have been critically engaged have no more been absolutely superseded than the conditions they addressed themselves to. ${ }^{60}$ The critique of the phantasmagoria, then, though of course in need of rethinking in relation to the specific terms of financialization - as suggested in this essay's brief remarks on the subject - may serve as one useful point of contact in radical philosophy's re-encounter with architecture. 
${ }^{1}$ This collaboration between Eisenman and Derrida began in 1985. In 1989, however, Derrida published a letter to the architect in which he repudiated the latter's understanding of deconstruction and publicly severed his connection with architectural deconstructivism. Jacques Derrida ‘A letter to Peter Eisenman', trans. Hilary P. Hanel in Assemblage No. 12, August, 1990, Cambridge: MIT Press, pp. 613.

${ }^{2}$ The author has written elsewhere, and at greater length, on this Deleuzian turn in architectural theory. See Douglas Spencer, 'Architectural Deleuzism: neoliberal space, control and the 'Univer-city"' in Radical Philosophy 168, July/August, 2011, pp. 9-21, and also Douglas Spencer, 'Architectural Deleuzism II: The possibility of critique' at: http://terraincritical.wordpress.com/2012/03/24/architecturaldeleuzism-ii-the-possibility-of-critique/

${ }^{3}$ Gilles Deleuze, The Fold: Leibniz and the Baroque, trans. Tom Conley, London: The Athlone Press, 1993.

${ }^{4}$ Gilles Deleuze \& Félix Guattari, A Thousand Plateaus: Capitalism and Schizophrenia, trans. Brian Massumi, London and New York: Continuum 1992. ${ }^{5}$ Greg Lynn (ed), Folding in Architecture, Chichester and Hoboken, NJ: WileyAcademy, 1993/2004 (reprinted).

${ }^{6}$ Jeffrey Kipnis, 'Towards a New Architecture' in Lynn, op. cit., p. 18.

${ }^{7}$ Deleuze and Guattari cautioned against any straightforward conception of smooth space as in itself liberatory or salvational in A Thousand Plateaus: 'Never believe that a smooth space will suffice to save us', op. cit., p. 500.

${ }^{8}$ See, for example, Jesse Reiser and Nanako Umemoto, Atlas of Novel Tectonics, New York: Princeton Architectural Press, 2006; Patrik Schumacher, 'Research Agenda', in Brett Steele (ed), Corporate Fields: New Environments by the AA DRL, London: AA Publications, 2005; Patrik Schumacher, Digital Hadid: Landscapes in Motion, Basel: Birkhäuser, 2003; Alejandro Zaera-Polo and Roemer van Toorn 'Educating the Architect', 2008, at: http://www.xs4all.nl/ rvtoorn/alejandro.html ${ }^{9}$ Jeffrey Kipnis, 'Towards a New Architecture' in Lynn, op. cit., p. 18.

${ }^{10}$ François Cusset, 'Theory (madness of),' in Radical Philosophy 167, May/June, 2011, p. 25.

${ }^{11}$ Ibid. 
12 Ibid., p. 24.

${ }^{13}$ K. Michael Hays, 'Introduction', Architecture Theory since 1968, ed. K. Michael Hays, Cambridge: MIT Press, 1998, p. xi.

${ }^{14}$ Michael Speaks, "Intelligence after theory" in Perspecta 38: Architecture After All, Cambridge: MIT Press, 2006, p. 103

${ }^{15}$ Robert Somol and Sarah Whiting, 'Notes around the Doppler effect and other moods of modernism', Perspecta 33: Mining Autonomy, 2002

${ }^{16}$ Zaera-Polo and van Toorn, 2008, op. cit.

${ }^{17}$ Jeffrey Kipnis, 'On the Wild Side', in Farshid Moussavi, Alejandro Zaera-Polo, and Sanford Kwinter (eds), Phylogenesis: FOA's Ark, Barcelona: Actar, 2004, p. 579.

${ }^{18}$ Lars Spuybroek, The Sympathy of Things: Ruskin and the Ecology of Design, Rotterdam: V2_Publishing, 2011, p. 264.

${ }^{19}$ Ibid.

${ }^{20}$ Kipnis, 2004, op. cit., p. 571.

21 Spuybroek, op. cit., p. 174.

${ }^{22}$ Ibid.

${ }^{23}$ Alejandro Zaera-Polo 'The Politics of the Envelope', Volume \#17, Fall 2008, p. 89.

${ }^{24}$ Sylvia Lavin, Kissing Architecture, Princeton: Princeton University Press, 2011, p. 30.

${ }^{25}$ Patrik Schumacher, The Autopoiesis of Architecture; Volume II: A New Agenda for Architecture, Chichester: Wiley, 2012, p. 135.

${ }^{26}$ According to Schumacher, the bounds by which architecture is circumscribed, as an autopoietic system, foreclose the very possibility of its exercising any critical faculties or political agency. Schumacher insists that architecture's accommodation of the existing social order must now be absolute since 'it is not architecture's societal function to actively promote or initiate political agendas that are not already thriving in the political arena.' Ibid., p. 447.

${ }^{27}$ Manuel De Landa's 'assemblage theory' models all modes of organisational processes as 'isomorphic' operations occurring at different scales across the biological, the geological and the social. This model, a kind of 'flat ontology', allows for causal agency between different 'singularities' but admits of no encompassing force directing them toward a preconceived end. See Manuel De Landa, $\underline{\mathrm{A} N e w}$ Philosophy of Society: Assemblage Theory and Social Complexity, London and New 
York: Continuum, 2006. Zaera-Polo, following De Landa, argues in 'The Politics of the Envelope' that 'In fact, it may be good to stop speaking of power in general, or of the State, Capital, Globalization in general, and instead address specific power ecologies comprising a heterogeneous mixture of bureaucracies, markets, antimarkets, shopping malls, airport terminals, residential towers, office complexes etc.' ZaeraPolo, (2008), op. cit., p. 101.

${ }^{28}$ Bruno Latour's 'actor-network theory', conceived along similar lines to De Landa's 'assemblage theory', recognizes no hierarchies within any system, only agents human and non-human — interacting amidst a network within which there are no privileged centers. Bruno Latour, a figure increasingly prominent within design and architectural discourse, has argued against the 'negativity' of critique, and suggested that it has, in any case, 'run out of steam', that 'Critical theory died away long ago'. See, Bruno Latour, 'Why Has Critique Run out of Steam? From Matters of Fact to Matters of Concern', in Critical Inquiry - Special issue on the Future of Critique, Vol 30 no 2 , p. 248.

${ }^{29}$ Manuel De Landa has argued that Deleuze and Guattari's attachments to Marx represent their own Oedipus complex, from which his own philosophy liberates their thinking. See Manuel DeLanda, John Protevi and Torkild Thanem 'Deleuzian Interrogations: A conversation with Manuel De Landa, John Protevi and Torkild Thanem', in Tamara: Journal of Critical Postmodern Organization Science, Vol 3 (4) 2005. For a critique of DeLanda's de-Marxification of Deleuze and Guattari see Eliot Albert, 'A Thousand Marxes', in Mute, Autumn 1998, at http://www.metamute.org/en/A-Thousand-Marxes

${ }^{30}$ Don Tapscott, The Digital Economy: Promise and Peril in the Age of Networked Intelligence, New York: McGraw-Hill, 1996, p. 53.

${ }^{31}$ Christopher Meyer and Stan Davis, It's Alive: The Coming Convergence of Information, Biology, and Business, New York: Crown Business, 2003, p. 33.

${ }^{32}$ Patrik Schumacher, 'Research agenda', in Brett Steele (ed), Corporate Fields: New Environments by the AA DRL, London: AA Publications, 2005a, p. 76.

${ }^{33}$ Ibid., p. 79.

${ }^{34}$ Zaera-Polo, (2008), op. cit., p. 103.

${ }^{35}$ Zaera-Polo, 'Order out of chaos: The material organization of advanced capitalism', in Architectural Design Profile, 1994, 108, p. 28. 
${ }^{36}$ Gilles Deleuze, 'Postscript on Control Societies', in. Negotiations, 1972-1990, trans. Martin Joughin, New York and Chichester: Columbia University Press, 1995. ${ }^{37}$ Gilles Deleuze, 'Control and Becoming', in Gilles Deleuze, Negotiations, 19721990, trans. Martin Joughin, New York; Chichester: Columbia University Press, 1995, p. 175

${ }^{38}$ Michel Foucault, Discipline and Punish: The Birth of the Prison, trans. Alan Sheridan, London: Penguin, 1977, p. 211.

${ }^{39}$ Michel Foucault, The Birth of Biopolitics: Lectures at the College De France, 197879, Michel Senellart (ed), trans. Graham Burchell, Basingstoke/New York: Palgrave MacMillan, 2008, p. 259-60.

${ }^{40}$ Luc Boltanski and Eve Chiapello, The New Spirit of Capitalism, trans. Gregory Elliot, London and New York: Verso, 2007.

${ }^{41}$ Ibid., p. 80.

${ }^{42}$ See, Paolo Virno, 'General Intellect', trans. Adrianna Bove, 2000, at: http://www.generation-online.org/p/fpvirno10.htm; Paolo Virno, A Grammar of the Multitude, trans. Isabella Bertoletti, James Cascaito and Andrea Casson, Los Angeles and New York: Semiotext(e), 2004; Maurizio Lazzarato, 'Immaterial Labour', in Hardt, Michael \& Virno, Paolo (eds), Radical Thought in Italy: A Potential Politics, Minneapolis and London: University of Minnesota Press, 1997; Christian Marazzi , Capital and Affects: The Politics of the Language Economy, trans. Giuseppina Mecchia, Los Angeles and New York: Semiotext(e), 2011; Antonio Negri, Marx Beyond Marx: Lessons on the Grundrisse, trans. Harry Cleaver, Michael Ryan and Maurizio Viano, New York: Autonomedia, 1991

${ }^{43}$ Lazzarato, (1997), op. cit., p. 142.

${ }^{44}$ Maurizio Lazzarato, The Making of the Indebted Man: An Essay on the Neoliberal Condition, trans. Joshua David Jordan, Los Angeles and New York: Semiotext(e), 2012, pp. 107-8.

45 Jonathan Crary, 24/7: Late Capitalism and the Ends of Sleep, London and New York: Verso, 2013, p. 9.

${ }^{46}$ See Hays, (1998), op. cit., for a more detailed account of 'transcoding'.

${ }^{47}$ Karl Marx, Capital, Volume I. trans. Ben Fowkes, London: Penguin, 1976, pp. 1645. ${ }^{48}$ Ibid., p. 165. 
${ }^{49}$ Ibid., p. 165.

${ }^{50}$ Paolo Virno, 'The Ambivalence of Disenchantment' in Hardt and Virno, (1997), op. cit., p. 33

${ }^{51}$ Theodor Adorno, In Search of Wagner, trans. Rodney Livingstone, London and New York: Verso, 2005, p. 74

52 Ibid.

${ }^{53}$ Susan Buck-Morss, 'Aesthetics and anaesthetics: Walter Benjamin's Artwork essay reconsidered', October, Vol. 62 (Autumn, 1992), p. 25.

${ }^{54}$ Adorno, (2005), op. cit., p. 74.

${ }^{55}$ See Spencer, (2011), op. cit., for a more extensive analysis of this project.

${ }^{56}$ Adorno, (2005), op. cit., p. 89.

${ }^{57}$ Thomas Heatherwick, 'Pacific Hall', at: http://www.heatherwick.com/pacific-place/

${ }^{58}$ Buck-Morss, (1992), op. cit., p. 22.

${ }^{59}$ Crary, (2013), op. cit., pp. 37-38.

${ }^{60}$ Ibid., p. 36. 